\title{
Frequency and antimicrobial susceptibility patterns of bacterial agents isolated from wound infections of inpatients at a university hospital in Tehran
}

\author{
Atena Nemati ${ }^{1}$, Ensieh Masoorian ${ }^{2}$, Mohammadreza Rajabpour $^{3}$, Amir Darb Emamie ${ }^{4}$, Mehdi Jafari, \\ Mohammad Reza Pourmand $^{6}$ \\ 1- MSc, Department of Pathobiology, School of Public Health, Tehran University of Medical Sciences, Tehran, Iran. ORCID \\ ID: 0000-0001-6861-4824 \\ 2- MSc, Department of Pathobiology, School of Public Health, Tehran University of Medical Sciences, Tehran, Iran. ORCID \\ ID: 0000-0002-1788-336X \\ 3- MSc, Department of Pathobiology, School of Public Health, Tehran University of Medical Sciences, Tehran, Iran. ORCID \\ ID: 0000-0003-3395-5965 \\ 4- MSc, Department of Pathobiology, School of Public Health, Tehran University of Medical Sciences, Tehran, Iran. ORCID \\ ID: 0000-0001-7701-5647 \\ 5- BSc, Sina Hospital, Tehran University of Medical sciences, Tehran, Iran. ORCID ID: 0000-0002-8187-8187 \\ 6- Professor, Department of Pathobiology, School of Public Health, Tehran University of Medical Sciences, Tehran, Iran. \\ (Corresponding author), Tel: +982142933087, Email: mpourmand@tums.ac.ir, ORCID ID: 0000-0003-1280-5765
}

\begin{abstract}
Background and Aim: Wound infections, as a common nosocomial infection, are contributing factors to mortality. Determining the prevalence of common pathogens causing wound infections and their antibiotic susceptibility patterns plays a key role in the rapid treatment and prevention of such infections. This study aimed to analyze wound infections in hospitalized patients in a university hospital in Tehran and determine the antimicrobial susceptibility patterns of the isolated bacteria.

Materials and Methods: Data about 563 hospitalized patients from different wards of a university hospital, who had participated in the study from March 2017 to June 2019, were collected, and sample collection from the wounds was carried out. For the identification of pathogens, we used standard bacteriological techniques. The disk diffusion method was used to determine the antimicrobial susceptibility patterns of the isolates. Data were analyzed using SPSS 18.
\end{abstract}

Results: Among five hundred and sixty-three samples, $382(67.7 \%)$ had positive cultures. The most common isolated pathogens were Staphylococcus aureus (19.2\%), Escherichia coli (17.7\%), Acinetobacter spp. (14\%), Pseudomonas aeruginosa (13.6\%) and Klebsiella spp. (12.9\%). Fifty percent of the Staphylococcus aureus isolates were resistant to cefoxitin. Escherichia coli and Acinetobacter spp. were resistant to most of the antibiotics.

Conclusion: Our study found that pathogens causing wound infections were highly resistant to commonly prescribed antibiotics. Identifying the etiological agents of wound infection and their antibiotic susceptibility patterns is essential, especially for the treatment of elderly patients and those hospitalized in intensive care. This can assist in designing a therapeutic strategy for these types of infections.

Keywords: Bacterial Agents, Wound Infection, Antimicrobial Susceptibility, Nosocomial Infection

Received: Oct 3, 2019

Accepted: Sep 11, 2020

How to cite the article: Atena Nemati, Ensieh Masoorian, Mohammadreza Rajabpour, Amir Darb Emamie Mehdi Jafari, Mohammad Reza Pourmand. Frequency and antimicrobial susceptibility patterns of bacterial agents isolated from wound infections of inpatients at a university hospital in Tehran.SJKU. 2021;25(3):7184.

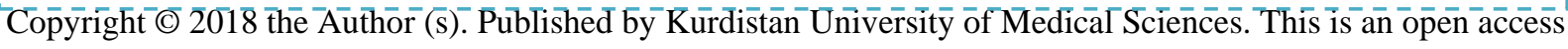
article distributed under the terms of the Creative Commons Attribution-Non-Commercial License 4.0 (CCBYNC), where it is permissible to download, share, remix, transform, and buildup the work provided it is properly cited. The work cannot be used commercially without permission from the journal 


\section{بررسى شيوع و تعيين الكوى حساسيت آنتى بيوتيكى عوامل باكتريايى عفونت هاى زخم

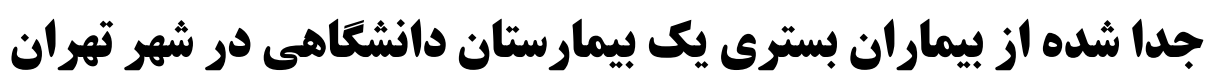

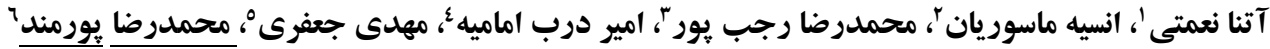

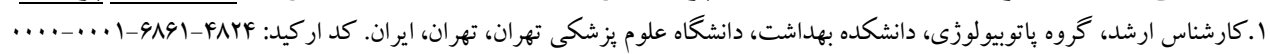

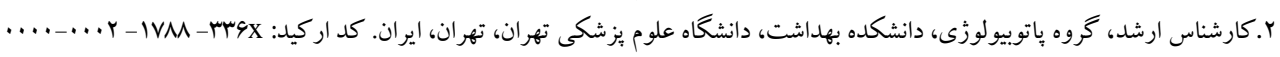

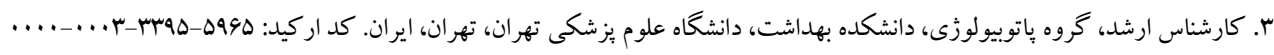

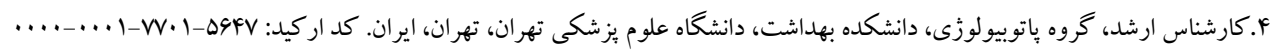

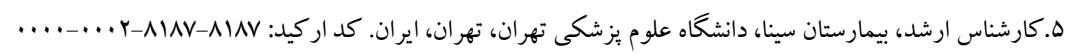

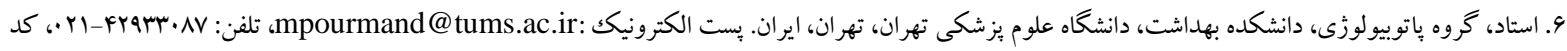
اركيد:

\section{جكيده}

زمينه و هدف: عفونت زخم به عنوان يكك عفونت بيمارستانى شايع، عامل مهمى در مركى و مير بيماران محسوب مى شود. تعيين

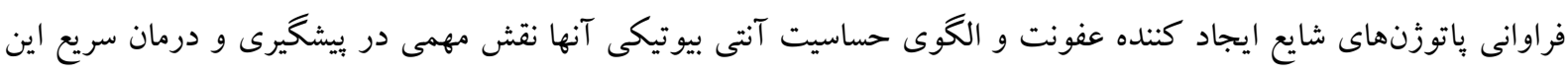

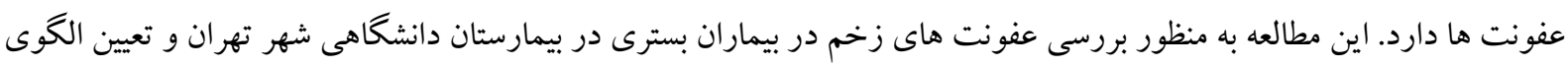

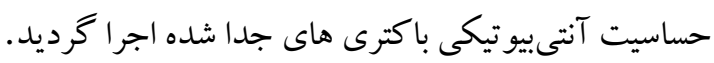

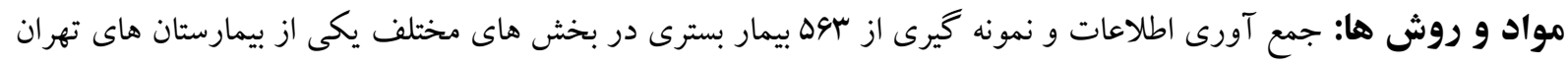

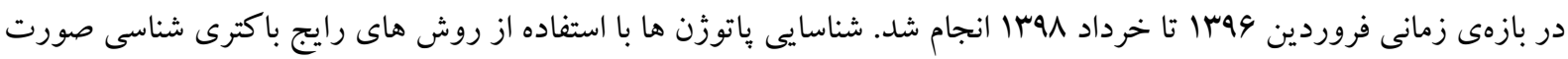

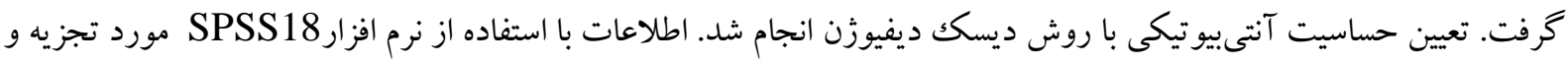
تحليل قرار گرفت.

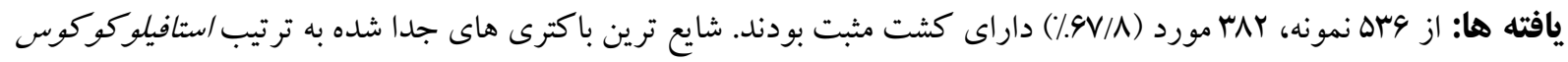

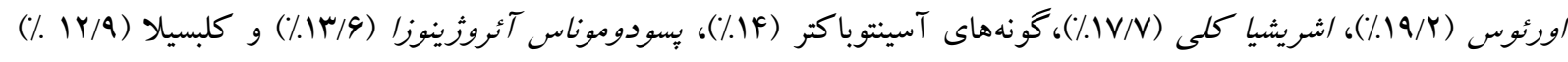
بودند. همجنين در نيمى از ايزوله هاى /ستافيلوكوكوس اورئوس مقاومت به سفو كسيتين مشاهده شد. ايزوله هاى آسينتوباكتر و و اشريشيا كلى به اغلب آنتى بيو تيكك ها مقاوم بودند. نتيجه كيرى: ياتوزن هاى عامل عفونت زخم به اغلب آنتى بيوتيككهاى رايج تجويزى مقاومت قابل توجهى نشان مى دهند. تعيين

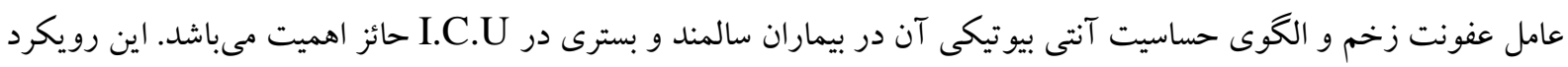
در تدوين راهبرد درمانى اين نوع از عفونت ها بسيار مهم است.

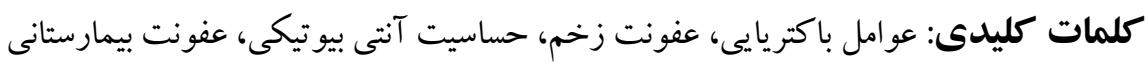
وصول مقاله: 9/V/11 اصلاحيه نهايى:99/9/0 يذيرش: 
عمل جراحى قرار مى گيرند را تهديد مى كند. اين نوع عفونتها، يّ از عفونت ادرارى به عنى عنوان شايع ترين

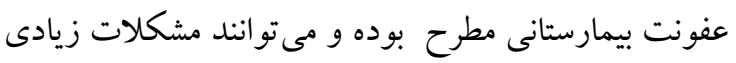

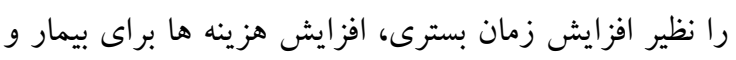

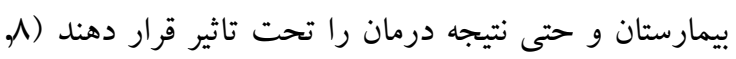

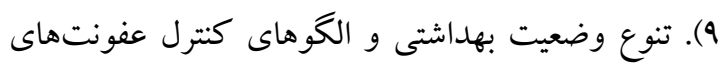
بيمارستانى در كشورهاى مختلف سبب غالب شدن سويه -

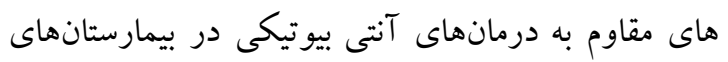

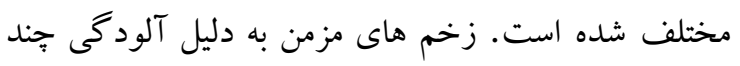

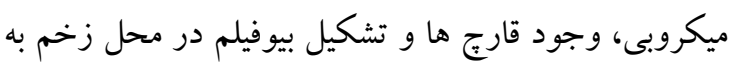
آنتى بيوتيكك هاى رايج ياسخ نمىدهند ( • (1). مطالعات نشان

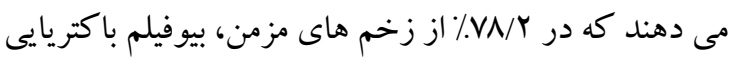

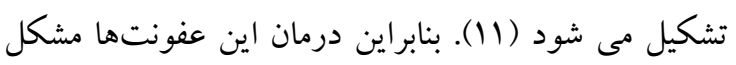
است و زخمهاى درمان نشده مى تواند به شكل عفونتهاى

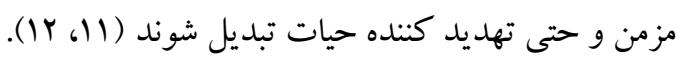
باتوزن هاى مختلفى در عفونت هاى زخم دخيل هستند. در

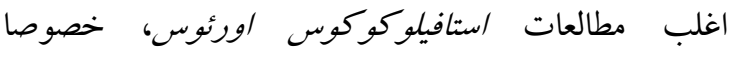
MRSA, ) استافيلوكوكوس /ورئوس مقاوم به متى سيلين (Methicillin-resistant Staphylococcus aureus عنوان شايع ترين عامل عفونت هاى زخم شناخته مى شوند

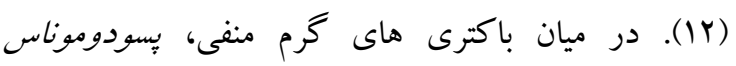

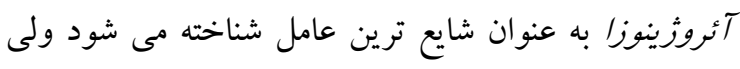

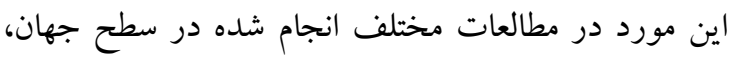
متفاوت است. به عنوان مثال در مطالعه انجام شده درد درد درد سنكايور باكترى آسينتوباكتر شيوع بالاترى نسبت به ساير ميكروار گانيسم هاى گرم منفى داشت (سا ). به دليل تجويز

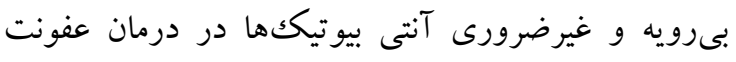

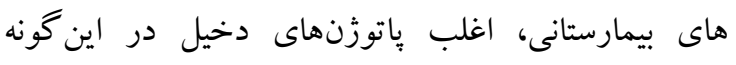

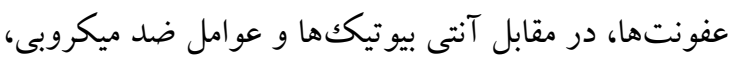

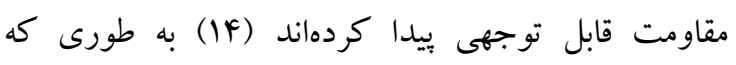
ايزوله هاى /ستافيلوكوكوس اورئوس نسبت به سفو كسيتين بيد

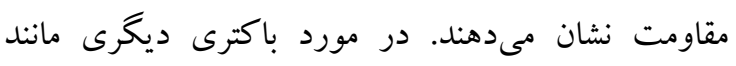

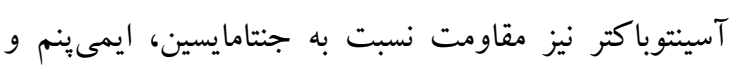

مقدمل عفونت زخم يكى از شايعترين عفونت بيمارستانى است كه با وجود كوششهاى فراوان در جهت جلو گيرى از بروز آنها، هنوز هم به عنوان يكى از مهمترين مشكلات بعد از عمل جراحى و همجينين در بيمارانى كه بهمدت طولانى در بيمارستان بسترى مىشوند، مىباشد (1, (Y). اين عفونتها در آمريكا هر ساله حدود يكك ميليون نفر را خرفتار مى كند (T) و حدود ها درصد از عفونتهاى بيمارستانى را در كشورهاى در حال توسعه به خود اختصاص مىدهد كه منجر به افزايش طول اقامت در بيمارستان ، افزايش هزينه ها و به خطر افتادن سلامت بيماران مىشود. زخم ها را معمولاً به سه كروه زخم هاى تميز، نيمه آلوده و آلوده تقسيم بندى مى كنند. برخى منابع نيز گروه ديخرى به نام زخم هاى عفونى را به اين دسته بندى اضافه مى كنند. عفونت زخمها در حال حاضر از شايع ترين عفونت هاى اكتسابى از

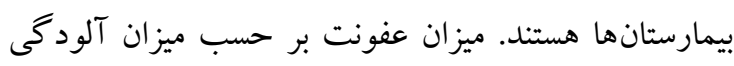
محل عمل و نوع بيمارى متفاوت است. تجويز آنتى بيوتيك بيش از عمل جراحى معمول مى باشد كه بر اين اساس ميز ان عفونت براى زخم هاى تميز، نيمه آلوده و آلوده به ترتيب:

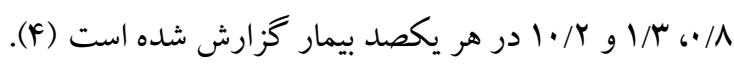
National براى تشخيص عفونت زخم بر طبق تعريف لبراي Nosocomial Surveillance هاى زير بايد وجود داشته باشد: الف) ترشح جركى (كشت مثبت ضرورى نيست)، ب) كشت مثبت از ترشحات زخم، ج) وجود حداقل يكى از علايم التهاب شامل درد يا حساسيت، اريتم و گرمى موضعى زخم و د) جراح يا يزشك مسئول، عفونت را تشخيص دهل. در واقع تشخيص زخم بر اساس يافته هاى كلينيكى است و معمولاً علايم بين روز هفتم تا دهم يس از عمل ظاهر مى شوند اكرجه ممكن است اين زمان بين MF ساعت تا دو هفته متغير باشد (Y, (V). عفونت زخم مشكلى بيجيجيده مىباشد كه همواره از اهميت زيادى برخوردار بوده است. عفونت محل عمل، خطر بالقوهاى است كه تمام بيمارانى را كه به هر دليلى تحت 
يذير نيست. براساس تعريف كلونيزاسيون كه به معناى رشد و تكثير عامل عفونى (ميكروار گانيسم) در ميزبان بدون ايجاد عفونت مى باشد. براى جلو گيرى از كلونيزه شدن باكترى ها

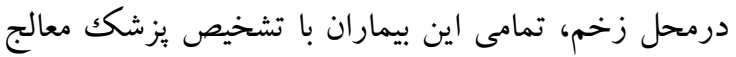

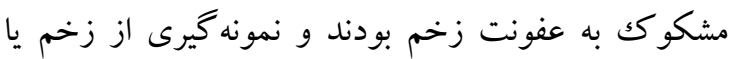

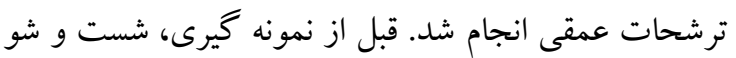

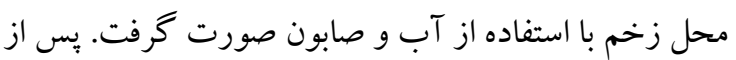
دبريدمان ناحيه مورد نظر، شست وشو با نرمالين سالين 9/٪ ٪

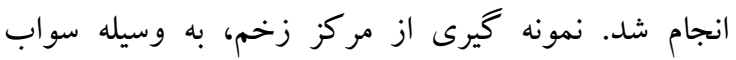

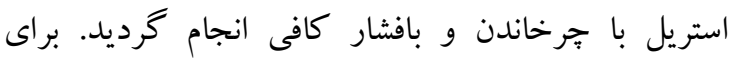

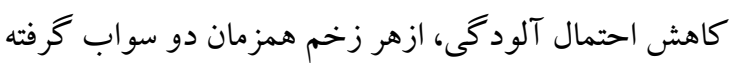
شد و سواب ها بلافاصله درداخل سرم فيزيولوزى استريل به

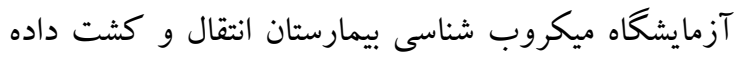

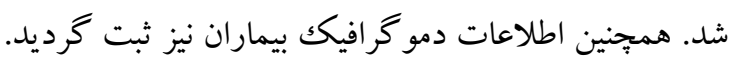

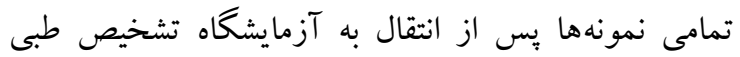

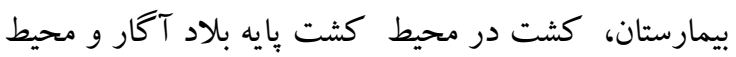
كشت انتخابى- افتراقى Eosin Methylene Blue و مكك كانكى (EMB)

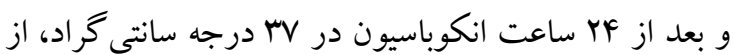
نظر وجود كلنى مورد بررسى قرار گرفتند (19).

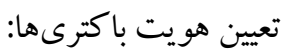
از تمامى بِليتهاى داراى كلنى مشكو ك،، اسمير تهيه و به روش گرم رنگك آميزى گرديد. ايزوله ها با استفاده از مورفولوزى كلنى ها، توليد رنخدانه در پِيودوموناس آئروثينوزا، رنخك آميزى گرم و تستهاى بيوشيميايى تعيين هويت شدند. براى شناسايى گونه هاى استافيلو كو كوس از تست هاى كاتالاز، كو آكولاز، مانيتول سالت آكار، DNAase

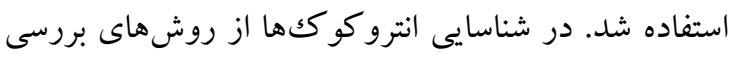
هموليز و ليز كلبول قرمز در اطراف كلنى باكترى، تحمل

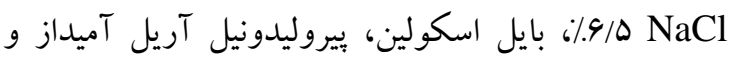

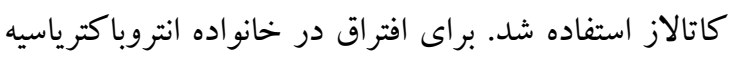
تست هاى مصرف كلوكز، لاكتوز و لايزين، سيمون
مروينم گزارش شده است (ها). مطالعات در كشور ما نشان داده است كه عامل اغلب عفونت هاى زخم، سويه هاى با مقاومت קند دارويى است. در ايران بيش از •^م درصد

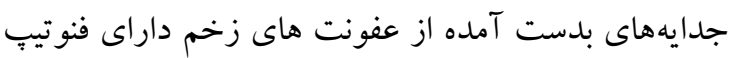
مقاومت جنددارويى بودند. درصد قابل توجهى از جدايه هاى استافيلو كو كوس اورئوس MRSA مى باشند و سطح بالايى از مقاومت به ايمى ينم در باكترى آسيتوياكتر بومانى دونى

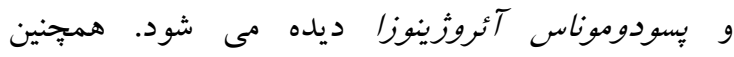

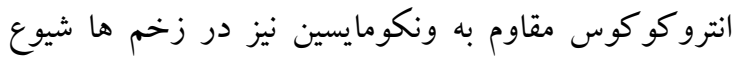
جشمخيرى دارد (1ه). با توجه به مطالب ذكر شده، عفونت زخم از مهم ترين و شايع ترين عفونت هاى بيمارستانى است و بررسى عوامل

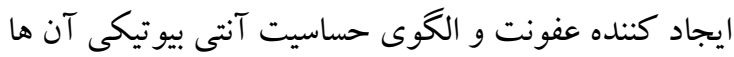
نقش بسزايى در درمان مناسب و جلو گيرى از گسترش

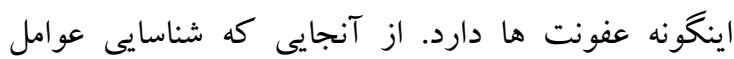
باكتريايى نقش بسزايى در كنترل عفونت و تعيين راهكارهاى مناسب درمانى در بخش هاى مختلف بيمارستان و كمكك به متخصصين در تجويز آنتى بيوتيك و كاهش مقاومت آنتى بيوتيكى دارد، بر آن شديم كه مطالعه ایى در زمينه شناسايى باكترىهاى عامل عفونتهاى زخم در يكك

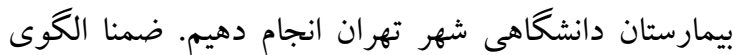
حساسيت آنتى بيوتيكى اين باكترىها تعيين گررديد.

\section{مواد و روش ها}

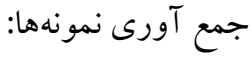
مطالعهى حاضر از نوع مقطعى- توصيفى بود. در بازهى

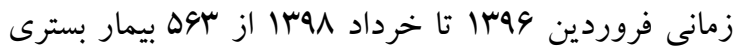
در بخش هاى مختلف بيمارستان دانشگاهى واقع در مركز تهران نمونه گيرى انجام شد.اين مطالعه با تاييديهى كميته

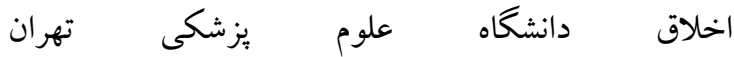
） (IR.TUMS.SPH.REC.1396.3203) يذيرفت. به دليل محدوديت هاى مطرح شده توسط كميته اخلاق امكان ذكر نام بيمارستان در متن اين مطالعه امكان 
(Clinical Laboratory Standards Institute-2019)

$$
\text { بررسى آمارى: }
$$

SPSS (IBM, در نهايت دادهها با استفاده از نرم افزار

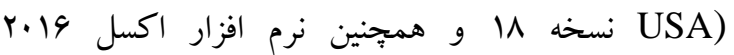
(Microsoft Office Excel, 2016) تحليل آمارى قرار گرفتند. ميانگين دادهها، درصد فراوانى و رسم نمودارها با استفاده از اين دو نرم افزار انجام شد.

\section{يافتهها}

از آن جايى كه تمايز بين كلونيزاسيون و عفونت در نمونه هاى بدست آمده از بيماران بسترى اهميت فراوانى دارد، خصوصيات بالينى بيماران با مشورت با متخصص عفونى و

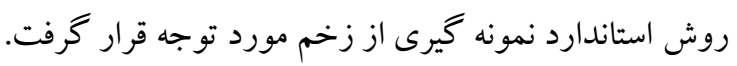

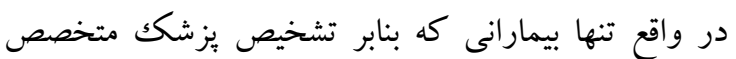

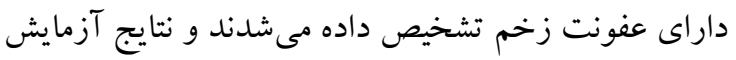

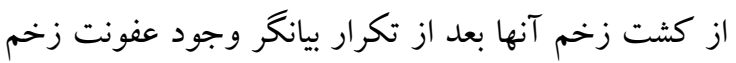
باكتريايى بود وارد مطالعه شدند. در اين مطالعه در مجموع تعداد سوها نمونه زخم در آزمايشگاه بيمارستان وابسته به ودانه

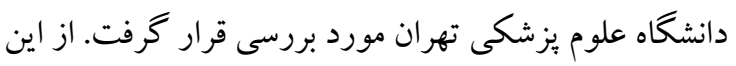

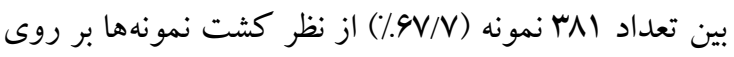

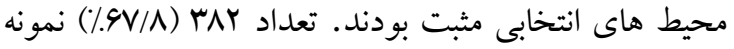

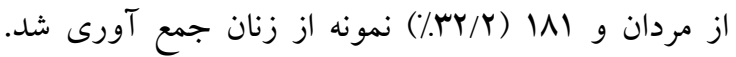
بيشترين تعداد نمونه مربوط به نمونه هاى زخم بيماران بسترى در بخش مراقبتهاى ويزٔه (I.C.U) با فراوانى

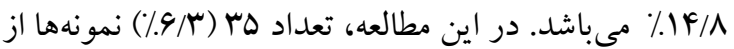

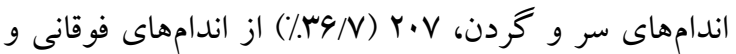
همجنين الب (هV/\%) از نمونه ها از اندامهاى تحتانى بيماران

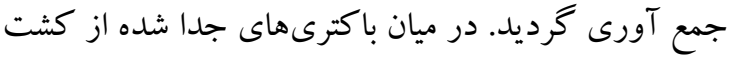
زخم، /ستافيلوكوكوس /ورئوس بيشترين فراوانى را داشت (19/1\%). فراوانى باكترىهاى جدا شده از نمونهاى كشت زخم در شكل ا نشان داده شده است. همجنين جدول 1
سيترات، وجود حركت، تجزيه اوره، توليد اندول، توليد H2 شناسايى باكترىهاى غير تخميرى نيز با كمك تست هاى مصرف لاكتوز و كلوكز در محيط Triple Sugar Iron Merck, Germany) Agar رنگدانه و DNAase صورت گرفت. تمامى موارد فوق

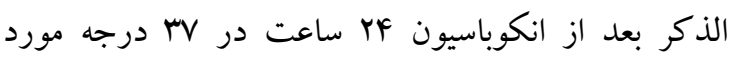

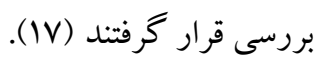
تعيين الكوى حساسيت آنتى بيوتيكى: براى بررسى مقاومت آنتى بيوتيكى ايزولهها از روش بيوني كربى بائر (Kirby-Bauer) استفاده شد. در اين روش ابتدا لترائا

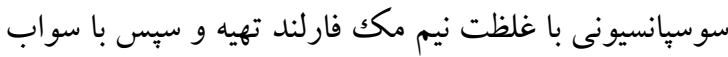

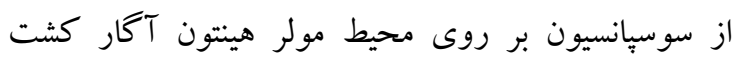
متراكم داده شد. در مرحلهى بعد ديسكهاى مورد نظر روى بِليت قرار داده شد و يس از زمان انكوياسيون كافى در

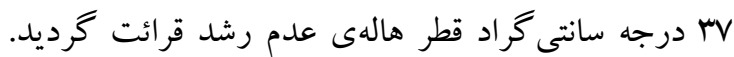
بمنظور انجام آزمون حساسيت آنتى بيوتيكى در باكترىهاى

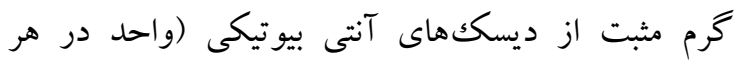
ديسك) استفاده شد: ترى متويريم-سولفامتو كسازول

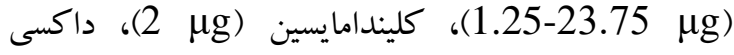
سايكلين ( 30 30)، سفازولين ( 30 3g )، سفو كسيتين ( 30

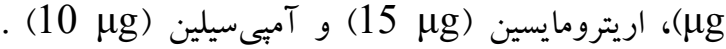
همجنين ديسككاى آنتى بيوتيكى مورد استفاده در باكترىهاى كرم منفى عبارتند از: ترى متويريمسولفامتو كسازول (23 بg 1.25.75)، جنتامايسين ( 10

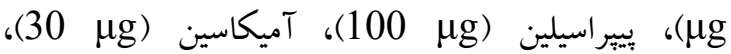

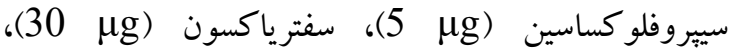
سفتازيديم (30 Mg) و ايمىينم (10 10). ديسككهاى آنتى بيوتيكى مورد استفاده از شركت روسكو مانسي (Rosco) Laboratories Inc, USA) و تفسير نتايج حاصل متناسب با هر باكترى و براساس

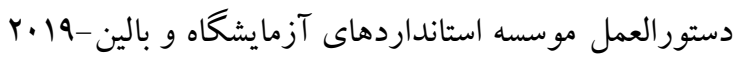


ميزان فراوانى باكترىها بر اساس سن، جنس و بخشى كه

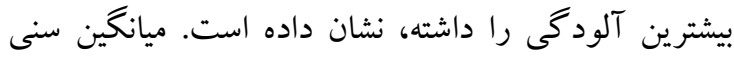

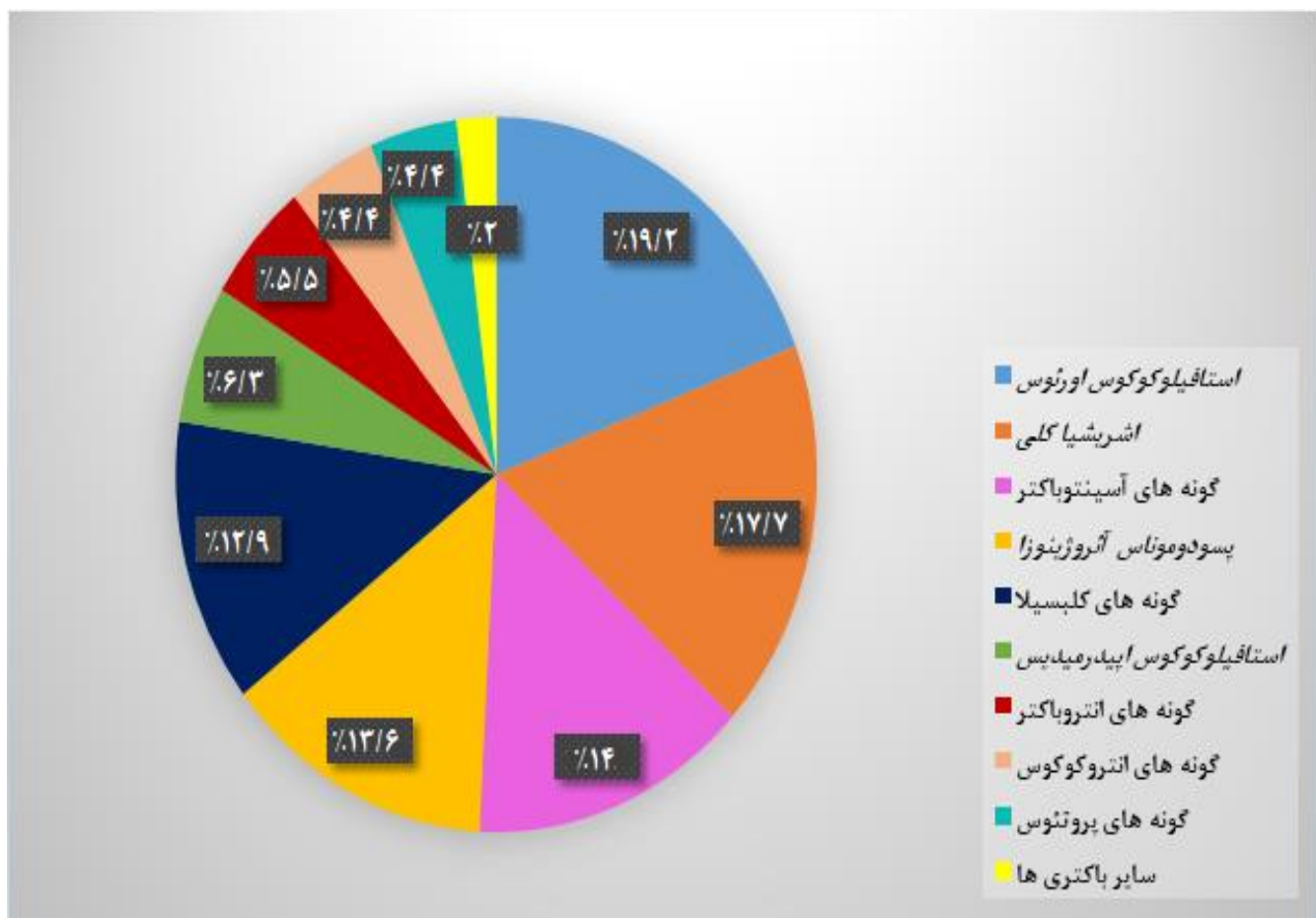

شكل ا: درصد و توزيع فراوانى باكترىهاى جدا شده از كشت زخم

ايزوله هاى كلبسيلا مقاومت بالايى نسبت به آنتى بيوتيكك-

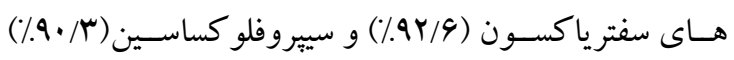
نشان دادند (شكل ץ). انتروباكتر به بيشتر آنتى بيوتيككهـاى مصرفى مانند ايمى ينم (س/\%ץ/\%) حساس بود. ميز ان حساسيت

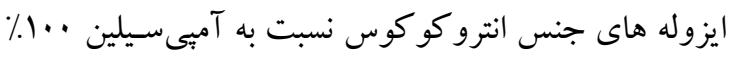
بوده و جنس بروتئوس نسبت بـه بيشـتر آنتى بيو تيككهـاى مصرفى حساسيت قابل توجهى از خود نشان داد (شكل \&).
در اين مطالعه، ·هـ/ از ايزولههاى /ستافيلوكوكوس /ورئسوس

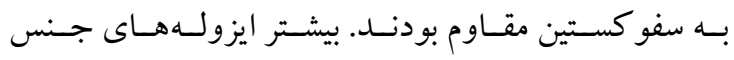
آسينتوباكتر به آنتىبيو تيككهاى مصرفى مقـاوم بـوده اسـت. بيش از • 9\% از ايزوله هاى /شريشيا كلى به ايمى ينم حساس و بيش از •Vl\% از آنها به سييروفلو كساسين مقاوم بودند (شـكل

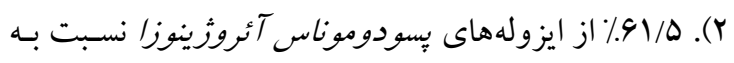
بييبراسيلين مقاوم و 94\% از آنها به ايمى بنم حساس بودند. 


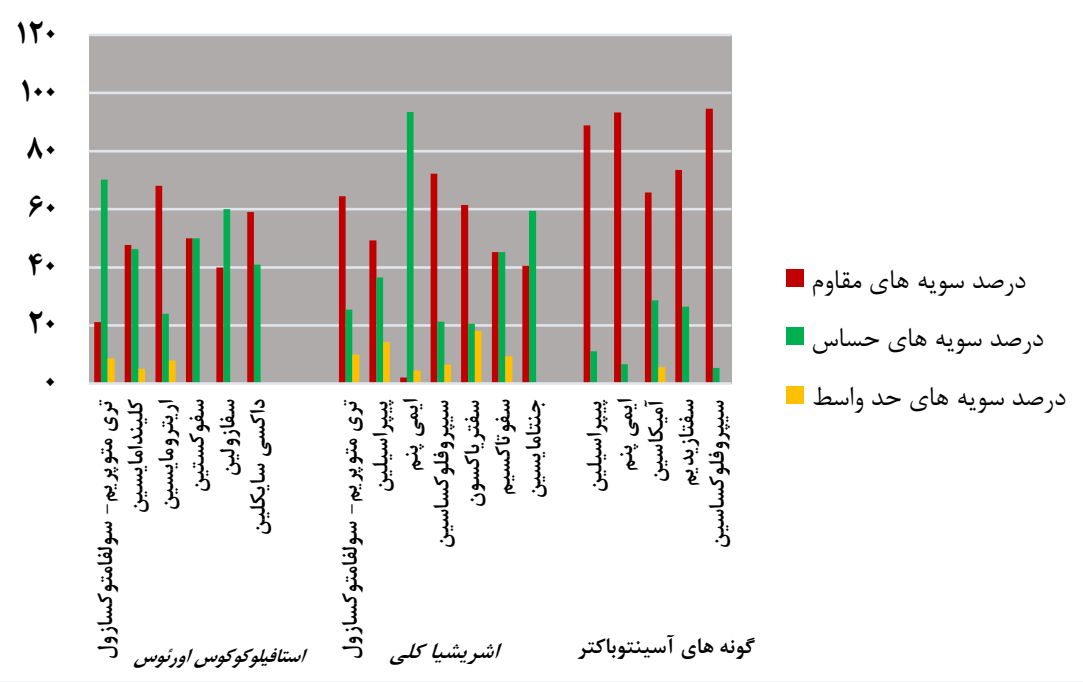

شكلr: الكوى حساسيت آنتى بيوتيكى ايزولههاى /ستافيلوكوكوس اورئوس، /شريشيا كلى و كونهاى آسينتو باكتر

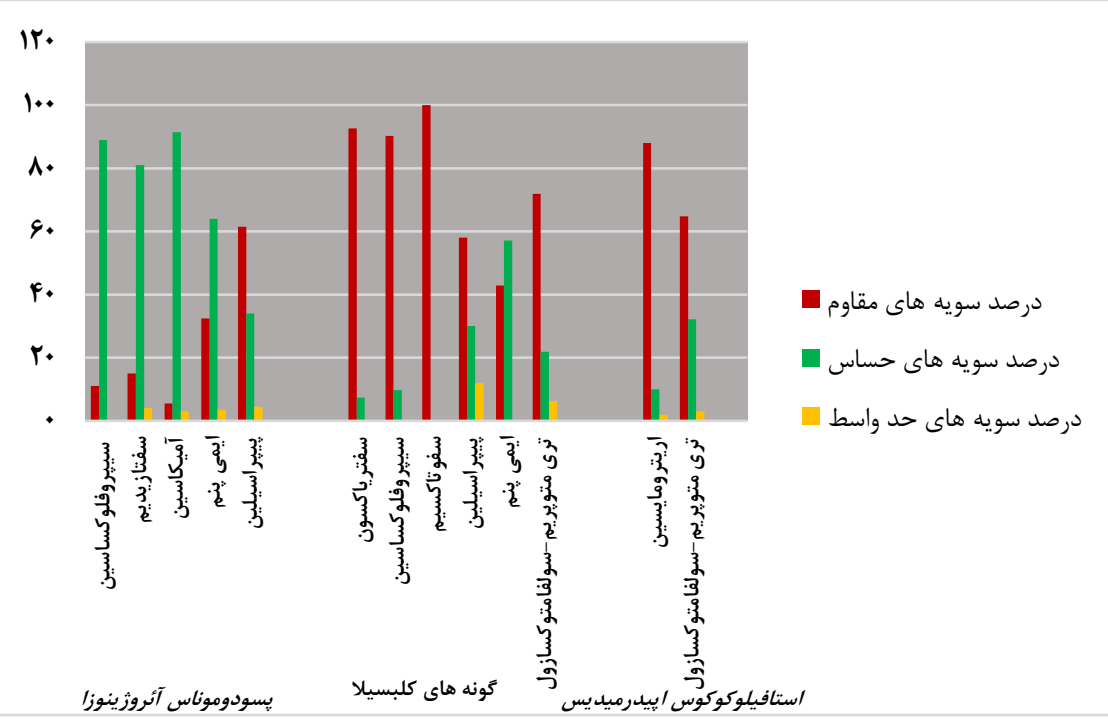

شكل : الكوى حساسيت آنتى بيوتيكى ايزوله هاى بسودوموناس آئروزينوزا، كونههاى كلبسيلا و استافيلوكوكوس /بيدرميديس 


\begin{tabular}{|c|c|c|c|c|c|c|}
\hline \multirow{2}{*}{ 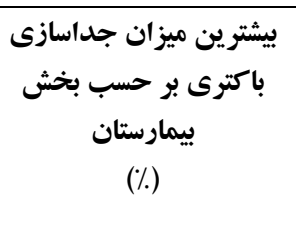 } & \multicolumn{3}{|c|}{ توزيع فراوانى باكترى بر اساس كروه بندى } & \multicolumn{2}{|c|}{ توزيع فراوانى بر حسب } & \multirow{3}{*}{ 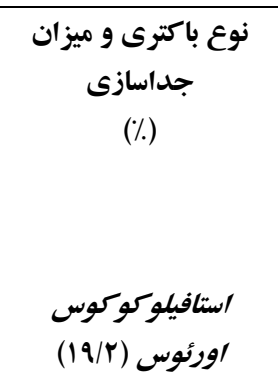 } \\
\hline & $\begin{array}{l}>0 \\
(\%)\end{array}$ & $\begin{array}{c}r \cdot-0 . \\
(\%)\end{array}$ & $\begin{array}{l}<r \cdot \\
(\%)\end{array}$ & $\begin{array}{l}\text { زن } \\
(\%)\end{array}$ & 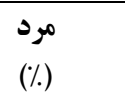 & \\
\hline اورزانس (IV/r) & $\Delta r / \Lambda$ & rq/r & $\cdot$ & $\mu \psi / 9$ & $90 / 4$ & \\
\hline داخلى مردان (YV/I) & $9 N / 1$ & $r \mid r$ & $\cdot$ & $r 9 / 9$ & $9 \cdot / 4$ & اشريشيا كلى (IV/Y) \\
\hline مراقبتهاى ويزه ( (YM/I) & $\Delta r / 9$ & $F F / V$ & $r / 9$ & $r 1 / 9$ & $9 N / 4$ & 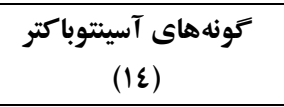 \\
\hline مر اقبتهاى ويزه (1N/9) & $F \Delta / q$ & $\Delta F / l$ & $\cdot$ & $\mathrm{rV} / \mathrm{A}$ & $9 T / Y$ & 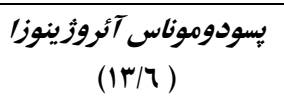 \\
\hline اورزانس (r. & 4. & $r V / l$ & $r / 9$ & $r \Delta / V$ & $V F / r$ & كونه هاى كلبسيلا (1 / ( ) \\
\hline داخلى زنان (IV/9) & $\Delta N / \Lambda$ & $r \Delta / r$ & $\Delta / 9$ & $r q / 4$ & $v \cdot / 9$ & 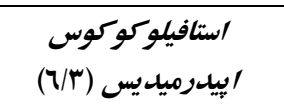 \\
\hline قلب و عروق (r.r) & $\Delta r / r$ & $r r / r$ & $1 \pi / r$ & r. & $\wedge$. & $\begin{array}{c}\text { كونههاى انتروباكتر } \\
\text { (0/0) }\end{array}$ \\
\hline جراحى عمومى (YD) & Vo & ro & . & ro & VD & $\begin{array}{c}\text { كونهاى انتروكو كوس } \\
\text { كواى (ع/ع) }\end{array}$ \\
\hline مراقبتهاى ويزه (YD) & $\Delta \Lambda / r$ & $F I / V$ & . & 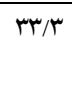 & $99 / \mathrm{N}$ & 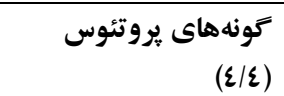 \\
\hline
\end{tabular}




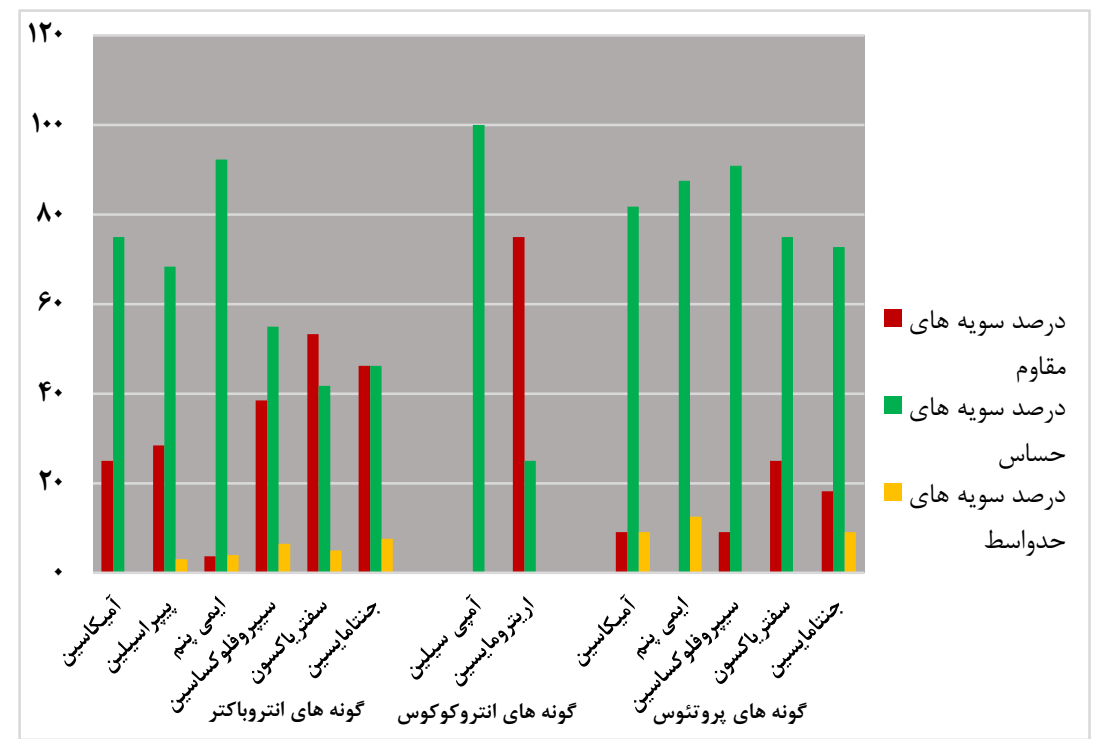

شكل ع: الكوى حساسيت آنتى بيوتيكى ايزولههاى كونههاى انتروباكتر، انتروكو كوس و يروتئوس

بود (·r). از بين بخشهاى مختلف بيمارستان، بخش

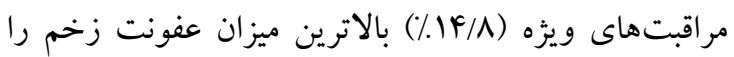
مرگك و مير ناشى از عفونتهاى زخم جالشى مهم در

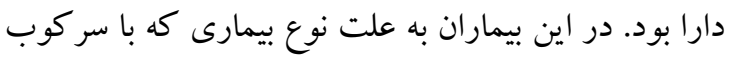
زمينهى سلامت است. همجنين افزايش مقاومت آنتى - معرى

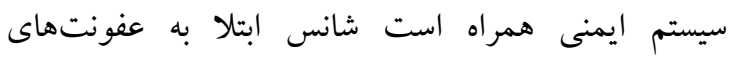

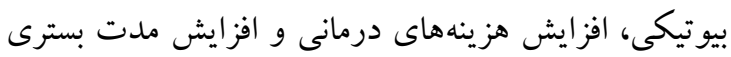
بيمارستانى به مراتب بالاتر مى رود. مطالعهدر بيمارستان، لزوم مطالعات مستمر در اين زمينه رادر هر فرئي ى Ebrahimzadeh و همكاران كه به بررسى عفونتهاى جامعه نشان مى دهد. در اين مطالعه ميانخين سن بيماران بيمارستانى در بيماران بسترى در بخش مراقبتهاى ويزه سال بود و به جز در مورد عفونت با ٍِودوموناس

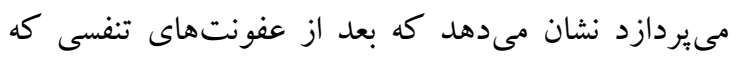

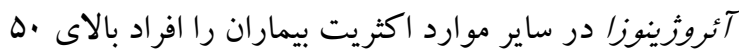

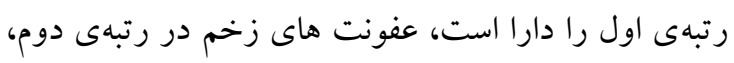

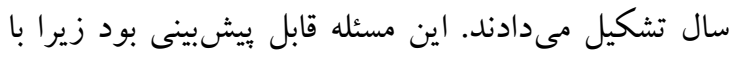

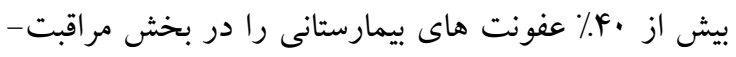
افزايش سن بيماران و تضعيف سيستم ايمنى شانس ابتلا به

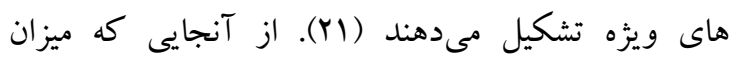
بيمارىهاى زمينهايى بيشتر مىشود كه اين موضوع مى تواند مصرف آنتىبيوتيككهاى وسيع الطيف در بخشه بهاى مر اقبت هاى ويزه بالا است، امكان ظهور سويههاى مقاوم نيز

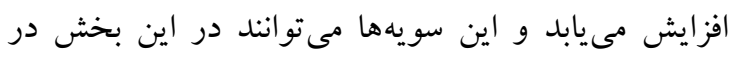

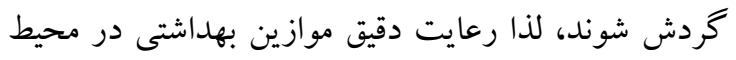
بويزه شست و شوى دستها در برسنل در كاهش اين در ايجاد عفونت نقش داشته باشد. در مطالعه Sherafat و

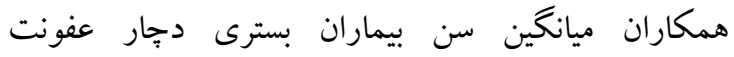
بيمارستانى كr سال بود (19). در مطالعات انجام شده در دران ساير كشورهاى جهان نيز افراد بالاى •ه سال به عفونت

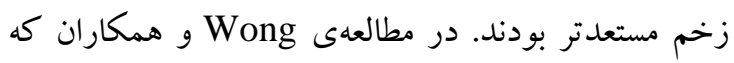

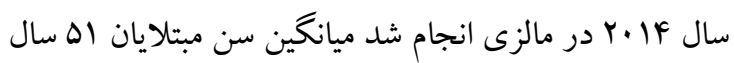


استافيلوكوكوس لورئوس مورد بررسى مقاومت به سفو كسيتين را نشان دادند، به اين معنا كه •هـ٪ ايزوله ها MRSA در در مطالعات مختلف ايران تفاوت جشمخيرى را نشان مى دهد ـ. در مطالعهى Goudarzi و همكاران كه در سال 19 19 به بررسى اين باكترى در عفونت هاى بيمارستانى مى بردازد شيوع ايزوله هاى مقاوم به متى سيلين A/ •V٪ اعلام شده است (YV). در بررسى ايزولههاى /ستافيلوكوكوس يروس اورئوس در بخش I.C.U بيمارستان لقمان، مشابه با مطالعه حاضر در حدود •ه درصد از ايزولهها مقاومت به متىسيلين را نشان دادند (Yq). Dormanesh و همكاران در سال ها Pr در يك بر برسى جامع عفونتهاى بيمارستانى در اطفال را مورد بررسى قرار دادند كه در اين ميان، ه؟ب٪ از تمامى ايزولههاى /ستافيلوكوكوس اورئوس، MRSA بودند

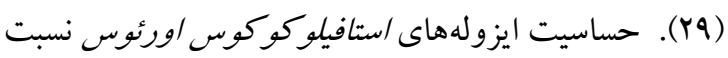
به ونكومايسين در اين مطالعه سنجيده نشد. اصولا مقاومت به ونكومايسين در اغلب نقاط جهان از جمله كشور ما بسيار نادر است در مطالعه Shekarabi و همكاران كه به بررسى F ايزوله /ستافيلوكوكوس /ورئوس يرداختند تنها IVA9 ايزوله مقاوم به ونكومايسين شناسايى شد (·r). مقاومت به كينولونها از مسائل نخران كننده در مورد عفونتهاى اشريشيا كلى است. در مطالعه حاضر نيز r/\% از جدايه ها به سيبروفلو كساسين مقاوم بودند و /9/0٪ نيز مقاومت حد واسط را نشان دادند. ميزان مقاومت به كينولون ها بستخى به جمعيت مورد مطالعه دارد براى مثال عفونتهاى بيمارستانى معمولا مقاومت بالاترى به آنتى بيوتيككها نشان مى دهند. در مطالعه Esfahani و همكاران كه در زمينه عفونتهاى بيمارستانى انجام گرديده است بيش از •هـ٪ از جدايهها به كينولونها مقاوم بودند ولى در مطالعه ديخرى كه به بررسى عفونتهاى ادرارى ناشى از اشريشيا كلى برداخته است در حدود VA از ايزولهها به سيبروفلو كساسين حساس بودند (اس، Yr). در مطالعه حاضر سطح پياينى از مقاومت به ايمىينم در اشريشيا كلى مشاهده شد در حالى كه گزارش مقاومت به كارباينم ها در اين باكترى بسيار متنوع بوده و در
عفونتها نقش بسزايى دارد (YY). باكترى كرم مثبت استافيلوكوكوس /ورئورس با فراوانى 19/1\% بيشترين شيوع را داشت و اشريشيا كلى، آسينتوباكتر و بِودوموناس آئروزينوزا در رتبههاى بعدى قرار داشتند. Ahmadi و همكاران در سال هوها در بيمارستان بقيه الله تهران به بررسى عوامل عفونتهاى زخم برداخت و مشابه مطالعه

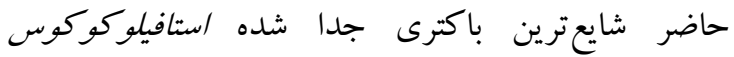
اورئوس بود. در اين مطالعه انتروكوكوس با شيوع بسيار جشمگيرى در رتبه دوم قرار گرفت كه فراوانى باكترى اخير با يافته هاى مطالعه ما تفاوت داشت (سY). در بررسى عفونتهاى بيماران بسترى در بخش I.C.U كه در بيمارستانهاى وابسته به دانشگاه علو م يزشكى شهيد بهشتى انجام شد، پِودوموناس آئروثينوزا و آسينتوباكتر به عنوان شايع ترين باكترىها گزارش شدند (19). در مطالعه مشابهى كه در كشور ايتاليا صورت كرفت نيز استافيلوكوكوس اورئوس شايعترين باكترى جداشده بود (YF) ولى در مطالعه Omoyibo آفريقايى نيجريه انجام گرفت، يسودوموناس آئروثينوزا به عنوان شايعترين باكترى شناسايى شد (YF)، YS). تفاوت در نوع ميكروار گانيسم و درصد شيوع در مطالعات مختلف به اين علت است كه ارگانيسمهاى هر منطقه جغرافيايى و هر بيمارستان مختص به همان مكان بوده و به عوامل محيطى مانند سطح بهداشت منطقه و در هر بيمارستان به بخش هاى بيمارستان، تعداد يذيرش بيمار، تعداد كاركنان درمانى و غيره بستخى دارد. ديخر نكته مهم در اين زمينه محل و نوع زخمهاى مورد بررسى مىباشد. به عنوان مثال در مطالعه Jafari است، در ميان ايزولههاى جدا شده از زخمهاى سوختكى، همانطور كه بيشبينى مىشد بِودوموناس آئروزينوزا فراوانى بالاترى نسبت به ساير باكترىها داشت (ها). در بررسى عفونت زخم ياى ديابتى كه در بيمارستان نمازى

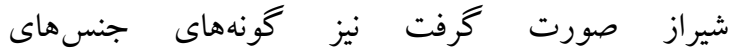
استافيلو كوكوس و انتروكوكوس بالاترين فراوانى را دارا بودند (Y9). در اين مطالعه نيمى از سويه سورى 
در بررسى اين مطالعه، نياز است تا به محدوديت هاى موجود در آن نيز اشاره شود. براى تشخيص باكترى ها در اين مطالعه از روش هاى رايج آزمايشگاهى استفاده شده است. استفاده از روش هاى خاص كشت ميكروبى براى اركانيسم هاى سخت رشد و دير رشد، مى تواند به شناسايى باكترى هاى متنوع كمكك شايانى كند. همجنين استفاده از روش هاى ملكولى نيز در اين موارد كمكك كننده است (MV) علاوه بر اين، تعيين حداقل غلظت مهارى در مورد ميكروار گانيسم هاى مقاوم مى تواند به دركك بهترى از سطح مقاومت بيانجامد.

\section{نتيجه كيرى}

باتوزنهاى عامل عفونت زخم به آنتى بيوتيككاى رايج مقاومت قابل توجهى نشان مىدهند. تعيين عامل عفونت زخم و الكوى حساسيت آنتىبيوتيكى آن در بيماران سالمند و بسترى در بخشهاى مراقبتهاى ويزه، كمكك زيادى به تدوين راهبرد درمانى اين نوع عفونتها مىنمايد.

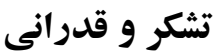

بودجه اين مطالعه از محل بودجه طرح هاى تحقيقاتى دانشگاه علوم پزشكى تهران تامين شده است. همبحنين اين اخلاق كد ب. مطالعه IR.TUMS.SPH.REC.1396.3203 اخلاق دانشگاه علوم يزشكى تهران مصوب گرديده است. در نهايت نويسندكان اين مقاله مراتب تشكر و قدردانى خود را از برسنل آزمايشگاه بيمارستان دانشگاه و همجينين عوامل گروه ياتوبيولوزى در دانشكده بهداشت دانشگاه علوم يزشكى تهران ابراز مى نمايند.
مطالعات سطح مقاومتى از صفر درصد تا حتى •له درصد نيز كزارش شده است (سM و سM). در مورد كلبسيلا مقاومت جشمخيرى نسبت به سفالوسيورينها و كينولونها وجود داشت و همجنين بيش از هـ٪ جدايها به ايمىينم مقاوم بودند. مقاومت سطح بالا به سفالوسبورينها در بسيارى از مطالعات انجام شده در شهر تهران به جشم مىخورد (MF). همجنين در مطالعهايى كه به بررسى عفونت هاى بيمارستانى در بخش I.C.U بيمارستانى در شهر تهران مى بردازد، ميزان مقاومت نسبت به كينولونها و كاربإنمها با مطالعه حاضر

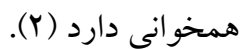
در باكترى آسينتوباكتر مقاومت به آنتى بيو تيككها، معضلى بسيار جدى و جالشى مهم محسوب مىشود. در مطالعه

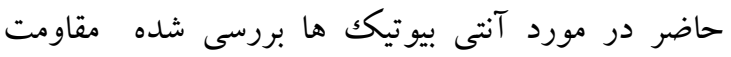

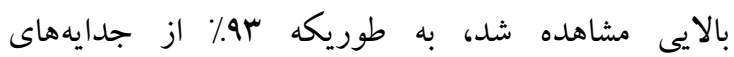
آسينتوباكتر نسبت به ايمىينم مقاوم بودند. در مطالعهايى كه اخيرا در تهران به بررسى عفونتهاى بيمارستانى ناشى از آسينتوباكتر يرداخته است نيز مشابه با مطالعه ما، سطح بالايى از مقاومت به اكثر آنتىبيوتيكها مشاهده كرديد(ها). همجنين در اين مطالعه بسيارى از باكترىهاى با مقاومت جند دارويى از نمونه هاى محيطى بيمارستان جداسازى شده است (هץ). در مورد باكترى غير تخميرى شايع ديخرى يعنى يسودوموناس آئروثينوزا مطالعه ما نشان داد كه همجنان بيش از •و\% جدايهها به كارباينمها حساس هستند كه اين ميزان حساسيت در مطالعه مشابهى كه در بيمارستان بقيه الله انجام كرفته نيز به جشم مى خورد (Yr). البته در مطالعهايى كه در سال وها بر بر روى عفونتهاى خون در يك بيمارستان دانشگاهى صورت گرفته است حساسيت بالاترى نسبت به كارباينم ها مشاهده شد كه اين موضوع مىتواند به عنوان زنگگ خطرى در زمينه ياتوزنهاى در گردش در اين بيمارستان محسوب شود (4).

\section{منابع}

1. Horan TC, Culver DH, Gaynes RP, Jarvis WR, Edwards JR, Reid CR, et al. Nosocomial infections in surgical patients in the United States, January 1986-June 1992. Epidemiology. $1993 ; 14(2): 73-80$. 
م براسى شيوع و تعيين...

2. Amini M, Ansari I, Vaseie M, Vahidian M. Pattern of antibiotic resistance in nosocomial infections with Gram-negative bacilli in ICU patients (Tehran, Iran) during the years 20122014.jpcp. 2018;6(1):23-30.

3. Kirkland KB, Briggs JP, Trivette SL, Wilkinson WE, Sexton DJ. The impact of surgicalsite infections in the 1990s: attributable mortality, excess length of hospitalization, and extra costs.

Infect Control Hosp Epidemio. 1999;20(11):725-30.

4. Shojaee H, Borjian S, Shoshtari por J, Arti H, Shirani S. Study of clean (Class I) surgical wound infections in Shahrekord and Borujen hospitals, 2000. J Shahrekord Univ Med Sci. 2002;4(3):1-7.

5. Horan TC, Gaynes RP, Martone WJ, Jarvis WR, Emori TG. CDC definitions of nosocomial surgical site infections, 1992: a modification of CDC definitions of surgical wound infections. Am J Infect Control. 1992;20(5):271-4.

6. Schwartz Seymour I. Principles of surgery. 7th edit. Mc Graw-Hill; 1999.

7. Bamberg R, Sullivan P, Conner-Kerr T. Diagnosis of wound infections: current culturing practices of US wound care professionals. Wounds.2002;14(9):314-28.

8. Wilson MA. Skin and soft-tissue infections: impact of resistant gram-positive bacteria. Am J Surg. 2003;186(5, Supplement 1):35-41.

9. Mok JM, Guillaume TJ, Talu U, Berven SH, Deviren V, Kroeber M, et al. Clinical Outcome of Deep Wound Infection After Instrumented Posterior Spinal Fusion: A Matched Cohort Analysis. Spine.2009,34(6): 548-83.

10. Malone M, Bjarnsholt T, McBain AJ, James GA, Stoodley P, Leaper D, et al. The prevalence of biofilms in chronic wounds: a systematic review and meta-analysis of published data. Journal of wound care. 2017;26(1):20-5.

11. Wolcott R, Rhoads D, Bennett M, Wolcott B, Gogokhia L, Costerton J, et al. Chronic wounds and the medical biofilm paradigm. J Wound Care. 2010;19(2):45-53.

12. Fallah F, Yousefi M, Pourmand MR, Hashemi A, Nazari Alam A, Afshar D. Phenotypic and genotypic study of biofilm formation in Enterococci isolated from urinary tract infections. Microb Pathog. 2017;108:85-90.

13. Chim H, Song C. Aeromonas infection in critically ill burn patients. Burns. 2007;33(6):756-9.

14. Shokrzadeh M, Rahbari Jeyd P, Mohammadpour A, Zaboli F, Mohammadnejad FZ, Ghaffari Charati M, et al. Frequency of exoT and exoS Genes among Pseudomonas Aeruginosa Isolates and Antibiotic Resistance in Burn Patients in Sari Zare Hospital, Iran. JMUMS. 2017;27(154):51-9.

15. Jafari R, Karbasizade V. Frequency and Antimicrobial Susceptibility of Acinetobacter baumannii in Burn infections in Isfahan, Iran. Adv. Biores. 2014;5(2):148-52

16. Rouhi S, Mohammadi B, Ramazanzadeh R, Mohammadi S, Zandi S. Prevalence of isolated bacterial and antibiotic resistant pattern of them in positive blood cultures isolated from patients admitted to different parts of Tohid Hospital of Sanandaj city (2013-2014). NNJ. 2016; 18 (60): 34-41. [In Persian]

17. Tille, Patricia M.,, and Betty A. Forbes. Bailey \& Scott's Diagnostic Microbiology. Fourteenth edition. St. Louis, Missouri: Elsevier, 2017.

18. CLSI. Performance Standards for Antimicrobial Susceptibility Testing. 29th ed. CLSI supplement M100. Wayne, PA: Clinical and Laboratory Standards Institute; 2019. Page 3268.

19.Evaluation of bacterial isolates and their resistance profiles in nosocomial bloodstream and surgical wound infections. J Res Med Sci. 2013;37(2):113-9. 
A

20. Wong SY, Manikam R, Muniandy S. Prevalence and antibiotic susceptibility of bacteria from acute and chronic wounds in Malaysian subjects. J Infect Dev Ctries. 2015;9(9):936-44.

21. Ebrahimzadeh A, Zare Bidaki M, Karbasi H, Khosravi S, Bijari B. An evaluation of culture-positive infections and risk factors in patients admitted to the ICU of Imam Reza hospital in Birjand in 2015-2016. Journal of Surgery and Trauma. 2017;5(3):74-80.

22. Cefalu JE, Barrier KM, Davis AH. Wound Infections in Critical Care. CRIT CARE NURS CLIN. 2017;29(1):81-96.

23. Ahmadi A, Soltanpour J, AA IF. Prevalence of polybacterial infection and antimicrobial susceptibility of wound samples from different wards. J Gorgan Univ Med Sci. 2016;18(1):120-7.

24. Bessa LJ, Fazii P, Di Giulio M, Cellini L. Bacterial isolates from infected wounds and their antibiotic susceptibility pattern: some remarks about wound infection. Int Wound J. 2015;12(1):47-52.

25. Omoyibo EE, Oladele AO, Ibrahim MH, Adekunle OT. Antibiotic susceptibility of wound swab isolates in a tertiary hospital in Southwest Nigeria. Ann. Afr. Med. 2018;17(3):110-6.

26. Anvarinejad M, Pouladfar G, Japoni A, Bolandparvaz S, Satiary Z, Abbasi P, et al. Isolation and antibiotic susceptibility of the microorganisms isolated from diabetic foot infections in Nemazee Hospital, Southern Iran. J. Pathog. 2015;2015.

27. Goudarzi M, Eslami G, Rezaee R, Heidary M, khoshnood s, Sajadi Nia R. Clonal dissemination of Staphylococcus aureus isolates causing nosocomial infections, Tehran, Iran. Iran J Basic Med Sci. 2019;22(3):238-45.

28. Salimi A, Kamalbeik S, Mahdavinejad A, Sabeti S, Talaie H. Methicillin Resistant Staphylococcus Aureus in Ventilator Associated Pneumonia in Toxicological Intensive Care Unit. ijt. 2014;7(23):962-6.

29. Dormanesh B, Siroosbakhat S, Khodaverdi Darian E, Afsharkhas L. Methicillin-Resistant Staphylococcus aureus Isolated From Various Types of Hospital Infections in Pediatrics: Panton-Valentine Leukocidin, Staphylococcal Chromosomal Cassette mec SCCmec Phenotypes and Antibiotic Resistance Properties. Jundishapur J Microbiol. 2015;8(11):e11341.

30. Shekarabi M, Hajikhani B, Salimi Chirani A, Fazeli M, Goudarzi M. Molecular characterization of vancomycin-resistant Staphylococcus aureus strains isolated from clinical samples: A three year study in Tehran, Iran. PLoS One. 2017;12(8):e0183607.

31. Esfahani BN, Basiri R, Mirhosseini SMM, Moghim S, Dolatkhah S. Nosocomial Infections in Intensive Care Unit: Pattern of Antibiotic-resistance in Iranian Community. Adv Biomed Res. 2017;6:54.

32. Ferdosi-Shahandashti E, Javanian M, Moradian-Kouchaksaraei M, Yeganeh B, Bijani A, Motevaseli E, et al. Resistance patterns of Escherichia coli causing urinary tract infection. Caspian J Intern Med. 2015;6(3):148-51.

33. Moini AS, Soltani B, Taghavi Ardakani A, Moravveji A, Erami M, Haji Rezaei M, et al. Multidrug-Resistant Escherichia coli and Klebsiella pneumoniae Isolated From Patients in Kashan, Iran. Jundishapur J Microbiol. 2015;8(10):e27517.

34. Heidary M, Nasiri MJ, Dabiri H, Tarashi S. Prevalence of drug-resistant Klebsiella pneumoniae in Iran: a review article. Iran J Public Health. 2018;47(3):3-17

35. Salehi B, Goudarzi H, Nikmanesh B, Houri H, Alavi-Moghaddam M, Ghalavand Z. Emergence and characterization of nosocomial multidrug-resistant and extensively drugresistant Acinetobacter baumannii isolates in Tehran, Iran. $\mathbf{J}$ Infect Chemother. 2018;24(7):515-23. 
36. Vahedi A, Baghani A, Baseri Z, Pourmand MR. Frequency and antibiotic resistance patterns of isolated bacteria from positive blood culture of hospitalized patients. Tehran Univ Med J.2018;75(12):902-12.

37. Afrough P, Pourmand MR, Sarajian AA, Saki M, Saremy S. Molecular investigation of staphylococcus aureus, coa and spa genes in ahvaz hospitals, staff nose compared with patients clinical samples. Jundishapur J.Microbiol.2013;6(4): ):5377. doi: 10.5812/jjm.5377. 